\title{
Peran Kepala Sekolah sebagai Manajer dalam Meningkatkan Partisipasi Masyarakat di SD Islam Az-Zahrah Palembang
}

\author{
Nursamsiah Siregar \\ SMA Negeri 15 Palembang, Indonesia \\ siregarnursamsiah@gmail.com
}

\begin{abstract}
This study aims to reveal the principal as a manager in increasing community participation, community participation in schools and the factors that support and hinder school principals as managers in increasing community participation in Islamic Az-Zahrah Elementary School in Palembang. This research includes field research, namely research by direct way to the place of research to observe and be directly involved with the object of research. This type of research is a qualitative case study research with inductive thinking logic, where this study has the characteristics that the data is stated in a reasonable state. This study uses qualitative methods, namely the methods of observation, interviews, and documentation. The results of the study are (1) school principals in increasing participation through service delegations, (2) Community participation in schools, both the community in general, and through school committees in providing advisory (advisory agencies), providing support (supporting agencies) overseeing the implementation of education in school (controlling agency) and the liaison between the school and parents of students (mediators) can be done well, (3) While the inhibiting factor in increasing community participation, especially parents, they do not have much time to participate directly in every school activity.
\end{abstract}

\section{Keywords: manager, factors, participation}

Abstrak. Penelitian ini bertujuan untuk mengungkapkan kepala sekolah sebagai manajer dalam meningkatkan partisipasi masyarakat, partisipasi masyarakat terhadap sekolah dan faktor-faktor yang mendukung dan menghambat kepala sekolah sebagai manajer dalam meningkatkan partisipasi masyarakat di SD Islam Az-Zahrah Palembang. Penelitian ini termasuk penelitian lapangan (field research) yaitu penelitian dengan cara langsung ke tempat penelitian untuk mengamati dan terlibat langsung dengan objek penelitiannya. Jenis penelitiannya ialah penelitian studi kasus yang bersifat kualitatif dengan logika berfikir induktif, dimana penelitian ini memiliki karakteristik bahwa datanya dinyatakan dalam keadaan sewajarnya. Penelitian ini menggunakan metode kualitatif, yaitu dengan metode observasi, wawancara, dan dokumentasi. Hasil penelitian yaitu (1) kepala sekolah dalam meningkatkan partisipasi melalui delegasi pelayanan, (2) Partisipasi masyarakat terhadap sekolah, baik masyarakat secara umum, maupun melalui komite sekolah dalam memberikan pertimbangan (advisory agency), memberikan dukungan (supporting agency) mengawasi penyelenggaraan pendidikan di sekolah (controlling agency) dan penghubung antara sekolah dengan orangtua siswa (mediator) dapat terlaksana dengan baik, (3) Sementara faktor penghambat dalam meningkatkan partisifasi masyarakat, hususnya orang tua, mereka tidak memiliki waktu banyak untuk ikut ber secara langsung pada setiap kegiatan sekolah.

Kata kunci: manajer, faktor, partisipasi

\section{PENDAHULUAN}

Manajerial pembelajaran dan lembaga pendidikan sebagai institusional yang baik, tentu dapat tercapai bila ada hubungan kemitraan antara institusi sekolah dengan masyarakat. Secara filosofis sekolah merupakan bagian integral dari masyarakat, sebab sekolah sebagai lembaga dan manajerial pembelajaran ada karena adanya dukungan dari masyarakat. 
Undang-Undang Standar Pendidikan Nasional No 20 tahun 2003. Lihat Sagala (2009: 246) pada pasal 4 ayat 6 menyatakan "Pendidikan diselenggarakan dengan memberdayakan semua komponen masyarakat melalui peran serta dalam penyelenggaraan dan pengendalian mutu layanan pendidikan". Pasal 54 ayat 2 menyatakan "serta masyarakat dalam pendidikan meliputi serta perorangan, kelompok, keluarga, organisasi profesi, dan organisasi masyarakat dalam menyelenggarakan dan pengendalian mutu layanan pendidikan". Masyarakat dalam melakukan hubungan dengan sekolah, sebagai lembaga pendidikan formal dan potensial dalam pembinaan generasi muda, khususnya bagi peserta didik pada jenjang pendidikan dasar.

Menurut Mulyasa (2011: 142) hubungan sekolah dengan orang tua atau masyarakat dapat dijalin melalui berbagai cara, misalnya mendatangkan orang tua atau tenaga khusus yang kebetulan ada di masyarakat. Bentuk kerjasama harus dilandasi, karenapertama, adanya kesamaan tanggung jawab; dalam undang-undang dikemukakan pendidikan adalah tanggung jawab bersama antara pemerintah, orang tua dan masyarakat.Kedua, adanya kesamaan tujuan; orang tua menghendaki putra-putrinya menjadi warga Negara dan manusia yang baik serta berguna bagi Negara dan bangsa; demikian pula para pendidik menghendaki agar peserta didiknya menjadi manusia sehat jasmani, rohani, terampil, kreatif, demokratis serta berguna bagi Negara dan Bangsa.

Bila kesamaan tanggung jawab dan kesamaan tujuan tidak diprogramkan secara manajerial yang efektif dan efesien maka program sekolah tidak akan berjalan dengan baik. Seperti: komite dianggap hanya sebagai stempel kepala sekolah, dalam artian semua program diatur dan ditentukan hanya oleh kepala sekolah. Pengurus komite yang biasanya super sibuk dengan urusan pribadinya, sehingga komite tidak memiliki ide kriatif dan inovatif untuk memajukan sekolah. Dilain pihak pengurus komite tidak memiliki niat dan iktikat yang kreatif, sehingga hanya mengikuti saja apa yang terbaik menurut kepala sekolah, ditambah lagi menjadi pengurus komite merupakan tugas pengabdian, padahal bukan rahasia lagi bagi bangsa ini, bahwa pengabdian itu hanya diucapan tidak sampai pada implementasi.

Padahal kemitraan dalam manajerial pendidikan antara masyarakat dan sekolah harus betul-betul diformulasikan dengan perencanaan, pelaksanaan, dan kontrol yang baik. Sehingga sekolah sebagai perpanjangan dari pemerintah untuk melaksanakan program-program yang telah diusung untuk membangun generasi yang berbudaya, berbangsa dan beragama dapat menjadi kenyataan melalui institusi pendidikan dan manajerial pengajaran yang efektif dan efesien. 
Kemitraan antara sekolah dan masyarakat tidak akan dapat tercapai bila tidak ada dukungan dari kepala sekolah, karena kepala sekolahlah yang berperan besar dalam melakukan hubungan kemitraan dengan masyarakat, sehingga masyarakat dapat berpartisipasi dengan baik dan positif. DidalamPeraturan Menteri Pendidikan Nasional Nomor 13 Tahun 2007 Tanggal 17 April 2007, tentang Standar Kepala Sekolah/Madrasah. Dalam peraturan tersebut terdapat lima dimensi kompetensi Kepala Sekolah yaitu: kepribadian, manajerial, supervisi, kewirausahaan, dan sosial. Setiap dimensi kompetensi memiliki sub-sub sebagai kompetensi dasar yang harus dimiliki seorang Kepala Sekolah.

Secara kompetensi seseoarang yang telah diangkat sebagai Kepala Sekolah, maka tidak diragukan lagi kelima kompotensi yang harus dikuasai oleh Kepala Sekolah, hanya yang perlu dikembangkan adalah; mampukah Kepala Sekolah membangun partisipasi masyarakat, sehingga sekolah sebagai institusi dan manajerial pembelajaran dapat dijadikan sebagai acuan kemajuan suatu bangsa. Sebab mundur-majunya suatu bangsa tergantung kepada pendidikannya.

Kepala sekolah sebagai guru yang diberi tugas tambahan lihat kamus besar bahasa Indonesia "guru kepala", diantara tugas tersebut ialah sebagai manajer. Deming dalam tulisan Usman (2007: 1) menuliskan bahwa 85 persen masalah mutu produksi bukan ditentukan oleh bawahannya melainkan oleh manajernya. Sejalan dengan pendapat Deming tersebut, Juran menyatakan bahwa masalah rendahnya mutu 80 persen ditentukan oleh manajemennya, sedangkan sisanya yang 20 persen oleh faktor lainnya.

Sesuai dengan tujuan utama manajemen sekolah adalah untuk mewujudkan sekolah yang efektif. Sekolah yang efektif ditentukan oleh kepemimpinan kepala sekolah yang efektif pula karena sukses atau gagalnya suatu sekolah sangatlah ditentukan oleh kehandalan kepemimpinan kepalanya. Pendapat Hechinger dan Townsent yang dikutip oleh Usman (2008: 1) dalam artikelnya Fungsi Kepala Sekolah/ Madrasah menuliskan: "Saya tidak pernah melihat sekolah yang bagus dipimpin oleh kepala sekolah yang buruk dan sekolah yang buruk biasanya dipimpin oleh kepala sekolah yang buruk pula. Saya juga menemukan sekolah yang gagal berubah menjadi sukses, sebaliknya sekolah yang sukses tiba-tiba menurun kualitasnya. Naik atau turunnya kualitas sekolah sangat tergantung kepada kualitas kepala sekolahnya."

Kepala Sekolah merupakan tonggak maju dan atau mundurnya suatu sekolah. Lebih lanjut menurut Usman (2008: 2) Kepala Sekolah tidak akan dapat melaksanakan tugasnya dengan baik apabila tidak ada dukungan dari masyarakat sekolah (stakeholders), diantaranya pendidik dan masyarakat 
lebih luas. Kepala sekolah harus mampu memanfaatkan sumberdaya gurugurunya (follower) untuk mendukung program briliannya.

Manajemen kepala sekolah bukanlah seperti manajemen tukang cukur, yang segala sesuatunya dilakukan oleh dirinya sendiri, baik dari mengasah pisau, mencukur, membersihkan dan seterusnya, tanpa melibatkan orang lain. Sebaliknya kepala sekolah berangkat dari defenisinya sebagai pemimpin ia harus dapat mempengaruhi seluruh masyarakat sekolah sehingga visi, misi, dan tujuan sekolahnya tercapai dengan baik.

Mutlak partisipasi masyarakat sangat menentukan keberadaan sekolah. Sebab keberhasilan pendidikan tidak hanya di tentukan oleh proses pendidikan di sekolah saja dengan tersedianya sarana dan parasarana yang lengkap, tetapi dapat ditentukan oleh faktor-faktor lain diantaranya parsisipasi masayarakat serta lingkungan keluarga. Karena pendidikan merupakan tanggung jawab pemerintah, masyarakat, dan orang tua murid. Hal ini mengisyaratkan bahwa masyarat dan lingkungan sekolah terutama orang tua murid mempunyai tanggung jawab untuk berpartisipasi terhadap penyelenggaraan pendidikan disekolah. Sesuai dengan amanat undangundang standar pendidikan.

Kepala sekolah sebagai manajer dalam meningkatkan partisipasi masyarakat di Sekolah Dasar Islam Az-Zahrah Palembang menarik untuk diteliti karena semejak sekolah dasar ini beroprasi sebagai institusi pendidikan dan manajerial pendidikan pada tahun ajaran 1992/1993 sampai saat ini animo masyarakat sangat tinggi, sehingga dugaan sementara peneliti sekolah ini memiliki kemitraan dengan masyarakat sangat baik.

Observasi peneliti pada tanggal 15 April 2013 dipagar sekolahnya tertulis ada beberapa seminar, diantaranya seminar psikologi mendidik anak dengan kasih sayang yang diperuntukkan bagi wali murid, seminar motivasi dan sukses ujian Nasional 2013 untuk siswa kelas enam, seminar tematik integrtif dan kurikulum 2013 untuk kepala sekolah dan dua utusan guru dari setiap sekolah. Ketiga acara tersebut berkerjasama dengan masyarakat, seperti komite sekolah atau orang tua, siswa, dan perusahaan.

Sekolah yang mewah dan mahal biasanya orang tua beranggapan masalah pendidikan bagi mereka merupakan tanggungjawab penuh bagi anak-anak mereka, karena mereka telah membayar dengan biaya pendidikan yang mahal. Hal ini juga yang membuat peneliti untuk membahas dan menelitinya lebih mendalam. Karena seperti yang peneliti kutip dari Ahmad (2008: 28) ketidak mampuan lembaga-lembaga seperti keluarga, masjid, dan lingkuangan yang mengelola pendidikan dalam melaksanakan tanggung jawabnya, karena itu di atas pundak sekolahlah tertumpu beban berat untuk mengajarkan dan mendidik tentang kebaikan, karena sekolah merupakan 
satu-satunya lembaga yang dapat mengkoordinir mereka secara massa dalam waktu sepanjang mungkin.

Dengan observasi ini semakin menjadikan peneliti tertarik untuk melakukan penelitian di SD Islam Az-Zahrah sebagai tempat penelitian yang berkaitan dengan kinerja kepala sekolah sebagai manajer dapat melakukan dan mendelegasikan nya sehingga dapat terjalin kerjasama-kerjasama dalam meningkatkan partisipasi masyarakat terhadap sekolah. Oleh karena itu penelitian ini berjudul Peran Kepala Sekolah sebagai Manajer dalam Meningkatkan Partisipasi Masyarakat di SD Islam Az-zahra Palembang.

\section{KAJIAN LITERATUR}

Kepala Sekolah dapat melaksanakan tugas-tugasnya dengan baik, asalkan kepala sekolah sesuai yang dikatakan oleh Surya Darma dan Usman (2008: 4) bahwa pemimpin itu dilahirkan bukan diciptakan (leader are born, not built). Pemimpin yang dilahirkan, maka ia dengan sendirinya menurut sunatullah atau hukum alam akan melalui proses pertumbuhan yang sempurna. Kesempurnaan itu terlihat dalam melakukan pekerjaan yang benar (do the right things) dan dengan cara yang benar (the things right).

Sejak lama diketahui bahwa terdapat dua an yang berbeda dalam kepemimpinan sekolah. Yang satu disebut kepemimpinan mengerjakan hal benar (do the right things). Hal ini ada hubungannya dengan visi dan arah. Kedua adalah an manajemen mengerjakan hal secara benar atau pelaksanaan (the things right). Jika orang berbicara tentang efektivitas menurut Rivai \& Murni (2009: 745), pada dasarnya mereka sedang berbicara tentang visi dan arah.Efektivitas dalam hubungan dengan memfokuskan energi sekolah ke suatu arah tertentu. Kalau orang berbicara mengenai efisiensi, mereka membahas sistem dan prosedur cara kerja dilaksanakan.

Efektif dan efisien kalau kita coba bandingkan dengan tugas pemimpin dan tugas manajer. Maka efektif merupakan olahan pemimpin, sedangkan efisien olahan manajer. Tugas pemimpin menurut Nasution (2001: 153) adalah mengembangkan visi (vision), menyesuaikan (alight), memberdayakan (empowering), melatih (coach), dan mempedulikan (care) dengan tujuan untuk memperbaiki sistem. Sedangkan tugas manajer merencanakan (plan), mengorganisasikan (organize), mengatur (direct) mengkoordinasikan (coordinate), dan mengendalikan (control) untuk memproleh hasil.

Menurut Hunsaker dalam tulisan Usman (2008: 27) Fungsi manajemen adalah: Planning, Organizing, Leading, and Controlling. Menurut Terry terdapat empat fungsi manajemen, yaitu :(1) planning (perencanaan); (2) organizing (pengorganisasian); (3) actuating (pelaksanaan); dan (4) controlling (pengawasan). 


\section{METODE PENELITIAN}

Peneliti dalam kajian ini menggunakan metode penelitian kualitatif, metode yang dipertentangkan dengan metode kuantitas yang berkaitan dengan 'kuantum' atau jumlah. Metodologi kualitatif merupakan sebagai prosedur penelitian yang menghasilkan data perilaku yang dapat diamati. Moleong (1991: 3) dengan metode ini peneliti dapat menyajikan secara langsung hakikat hubungan antara peneliti dan responden. Moleong (1991: 5) sehingga dapat menjawab permasalahan-permasalahan yang diteliti. Sesuai dengan formulasi rumusan masalah yang peneliti gunakan dalam penelitian ini.

Penelitian ini termasuk penelitian lapangan (field research) yaitu penelitian dengan cara langsung ke tempat penelitian untuk mengamati dan terlibat langsung dengan objek penelitiannya. Jenis penelitiannya ialah penelitian studi kasus yang bersifat kualitatif dengan logika berfikir induktif, dimana penelitian ini memiliki karakteristik bahwa datanya dinyatakan dalam keadaan sewajarnya.

Jenis data yang digunakan dalam penelitian ini merupakan data primer dan data sekunder. Data primer merupakan data yang peneliti dapatkan dengan menggunakan observasi, dokumentasi, dan wawancara, atau datadata yang diperoleh langsung dari informen, seperti kepala sekolah, wakil kepala sekolah, tenaga pendidik, dan masyarakat, baik orang tua atau masyarakat yang ada disekitar sekolah atau pengusaha-pengusaha. Data sekunder merupakan data pendukung yang sudah berbentuk, seperti bukubuku ilmiah, dokumen dan peraturan-peraturan yang berkaitan dengan penelitan yang dilakukan.

Untuk memperoleh data dalam penelitian ini, peneliti menggunakan beberapa metode dalam pengumpulan datanya, karena agar memperoleh data yang valid maka diperlukan berbagai metode, sebab masing-masing metode memiliki kelebihan dan kekurangan, sehingga satu dengan yang lainnya saling melengkapi. Dalam penelitian ini peneliti menggunakan pendekatan kualitatif deskriptif analisis. Penelitian ini bertujuan untuk mengungkapkan kepala sekolah sebagai manajer dalam meningkatkan partisipasi masyarakat, partisipasi masyarakat terhadap sekolah dan faktorfaktor yang mendukung dan menghambat kepala sekolah sebagai manajer dalam meningkatkan partisipasi masyarakat di SD Islam Az-Zahrah Palembang Penelitian ini menggunakan metode kualitatif, yaitu dengan metode observasi, wawancara, dan dokumentasi. 


\section{HASIL DAN PEMBAHASAN}

Hasil dari penelitian ini terdapat empat tahapan meliputi: perencanaan, pengorganisasian, pelaksanaan dan pengawasan. Berikut ini, penjelasan secara terperinci:

\section{- Perencanaan (planning)}

Perencanaan tidak lain merupakan kegiatan untuk menetapkan tujuan yang akan dicapai beserta cara-cara untuk mencapai tujuan tersebut. Sebagaimana disampaikan oleh Boone \& David (1984) bahwa: planning may be defined as the proses by which manager set objective, asses the future, and develop course of action designed to accomplish these objective. Sedangkan Handoko (1995) mengemukakan bahwa: "Perencanaan (planning) adalah pemilihan atau penetapan tujuan organisasi dan penentuan strategi, kebijaksanaan, proyek, program, prosedur, metode, sistem, anggaran dan standar yang dibutuhkan untuk mencapai tujuan. Pembuatan keputusan banyak terlibat dalam fungsi ini." Arti penting perencanaan terutama adalah memberikan kejelasan arah bagi setiap kegiatan, sehingga setiap kegiatan dapat diusahakan dan dilaksanakan seefisien dan seefektif mungkin. Handoko mengemukakan sembilan manfaat perencanaan bahwa perencanaan: (a) membantu manajemen untuk menyesuaikan diri dengan perubahan-perubahan lingkungan; (b) membantu dalam kristalisasi persesuaian pada masalah-masalah utama; (c) memungkinkan manajer memahami keseluruhan gambaran; (d) membantu penempatan tanggung jawab lebih tepat; (e) memberikan cara pemberian perintah untuk beroperasi; (f) memudahkan dalam melakukan koordinasi di antara berbagai bagian organisasi; (g) membuat tujuan lebih khusus, terperinci dan lebih mudah dipahami; (h) meminimumkan pekerjaan yang tidak pasti; dan (i) menghemat waktu, usaha dan dana.

Perencanaan merupakan langkah awal dari manajemen, namun menurut Dwi Martini (wawancara, 29 April 2013) di SDI Az-Zahrah bahwa perencanaan bukanlah langkah awal dalam pengelolaan manajemen sekolah, namun pendelegasianlah yang menjadi langkah awal dalam manajemen sekolah SDI Az-Zahrah. Menurut Management Representative (MR) SDI Az-Zahrah Muslimin (wawancara, 6 Mei 2013) bahwa pendelegasian memang harus dilakukan lebih awal, karena kebiasaan sekolah setelah menunjuk siapa diposisi apa? Maka manajemen sekolah akan bergulir ketahap berikutnya yaitu membuat program sasaran mutu. Sasaran mutu selalu merujuk kepada kebijakan mutu yang telah disepakati dan komitmen bersama pendidik dan tenaga kependidikan yang ada disekolah. Kemudian unit kerja sekolah yang lain menyusun sasaran mutu dengan memperhatikan sasaran mutu sekolah, 
setelah sasaran mutu disusun, maka harus dilengkapi dengan program cara pencapaiannya termasuk sumberdaya dan rekaman yang membuktikan bekerjanya suatu sistem.

Menurut Muslimin lebih lanjut, pada saat membuat sasaran mutu sekolah menggunakan prinsip SMART (spesific, measurable, achiveble, realistic, timeframe). Dalam artian sasaran mutu harus dibuat tidak seperti daftar keinginan. Spesifik bukan berarti bersifat umum tapi jelas programnya, dapat diukur lebih bersifat kuantitatif dalam artian program tidak dibuat muluk-muluk tetapi sesuai dengan daya yang ada, dapat dijangkau, realistis program yang tidak bersifat mimpi, dan ada batas waktu yang jelas untuk mencapai sasaran mutu tersebut.

Wawancara peneliti dengan Hubungan Masyarakat (HUMAS) SD Islam Az-Zahrah bapak Mustamiruddin (wawancara 2 Mei 2013) beliau menjelsakan bahwa seluruh yang berkaitan dengan dokumen, seluruh dokumen SD Islam Az-Zahrah merupakan dokumen terkendali, keluar masuk dokumen harus dikendalikan oleh MR yang dapat diproses melalui sekretaris MR, termasuk PK.

\section{- Pengorganisasian (organizing)}

Fungsi manajemen berikutnya adalah pengorganisasian (organizing). Terry (1986) mengemukakan bahwa: "Pengorganisasian adalah tindakan mengusahakan hubungan-hubungan kelakuan yang efektif antara orangorang, sehingga mereka dapat bekerja sama secara efisien, dan memperoleh kepuasan pribadidalam melaksanakan tugas-tugas tertentu, dalam kondisi lingkungan tertentu guna mencapai tujuan atau sasaran tertentu". Boone \& David (1984) mengartikan pengorganisasian: “... as the act of planning and implementing organization structure. It is the process of arranging people and physical resources to carry out plans and acommplishment organizational objective". Dari kedua pendapat di atas, dapat dipahami bahwa pengorganisasian pada dasarnya merupakan upaya untuk melengkapi rencana-rencana yang telah dibuat dengan susunan organisasi pelaksananya. Pendelegasian atau penunjukan seseorang atau tim untuk menempati posisi tertentu sehingga program yang telah direncanakan dapat terialisasi dengan baik. Menurut Kepala SD Islam Az-Zahrah sebagai manajer, Dwi Martini, pada saat diwawancara pada (29 April 2013) menjelaskan bahwa yang dilakukan oleh kepala sekolah sebagai manejer untuk meningkatkan partisipasi masyarakat adalah mendelegasikan tugas-tugas kepala sekolah kepada tenaga pendidik dan kependidikan yang tertulis dalam Job Description yang dikenal dengan jobdes. 
Sesuai dengan jobdes yang telah dibuat oleh kepala sekolah SD Islam Az-Zahrah, didalamnya memuat mengenai persyaratan-persyaratan seseorang yang dapat menempati posisi sebagai pejabat pada struktural yang telah ditentukan, baik persyaratan umum maupun persyaratan husus, tugas atau kewajiban, wewenang bagi Management Representative (MR) dan wakil-wakil kepala sekolah, dan alur komunikasi secara struktural dan atau komunikasi koordinasi. Pendelegasian tugas kepala sekolah sebagai manajer dalam meningkatkan partisipasi masyarakat dilakukan oleh kepala sekolah melalui Prosedur Kerja (PK) yang telah dibuat oleh setiap bidang dengan bimbingan dan pengawasan dari MR dan Kepala Sekolah.

Dalam pendelegasian tugas tentu ada persyaratan-persyaratan tertentu, menurut Ibu Dwi Martini (wawancara, 29 April 2013) telah dituliskan didalamjob discription (Jobdes) SDI Az-Zahrah, sebagai salah satu contoh peneliti cantumkan didalam penelitian ini jobdenya kepala sekolah sebagai berikut:

$\begin{array}{ll}\text { Nama Jabatan } & \text { : Kepala Sekolah } \\ \text { Bertanggung jawab kepada } & \text { : Badan Pelaksana Kegiatan Yayasan Az- } \\ & \text { Zahra Palembang. } \\ \text { Berkoordinasi dengan } & \text { : Pengawas TK/SD Kecamatan Ilir Barat I } \\ & \text { Palembang dan ka UPTD Kec. Ilir Barat I } \\ & \text { Palembang. }\end{array}$

Dari hasil obervasi peneliti dan data yang peneliti dapatkan baik dari dokumen terkendali maupun wawancara, maka peneliti dapat menyimpulkan bahwa pendelegasian guru dan pegawai selalu sesuai dengan potensi dan kompotensinya, dan bila tidak memenuhi persyaratan tersebut, maka sesuai hasil wawancara denga Muslimin (6 Mei 2013) mereka guru atau pegawai akan diberikan ilmu dan pengetahuan mengenai hal yang belum ia kuasai sesuai dengan tanggung jawabnya, baik melalui pelatihan internal atau eksternal. Dan bila hal tersebut mendesak untuk dikuasai oleh penanggung jawab, maka sekolah akan segera memanggil atau mengirim tutor atau mentor untuk memberikan ilmu pengetahuan yang berkaitan dengan tata kelolanya sebagai penanggung jawab.

\section{- Pelaksanaan (actuating)}

Dari seluruh rangkaian proses manajemen, pelaksanaan (actuating) merupakan fungsi manajemen yang paling utama. Dalam fungsi perencanaan dan pengorganisasian lebih banyak berhubungan dengan aspek-aspek abstrak proses manajemen, sedangkan fungsi actuating justru lebih menekankan pada kegiatan yang berhubungan langsung 
dengan orang-orang dalam organisasi. Dalam hal ini, Terry (1986) mengemukakan bahwa actuating merupakan usaha menggerakkan anggota-anggota kelompok sedemikian rupa hingga mereka berkeinginan dan berusaha untuk mencapai sasaran perusahaan dan sasaran anggotaanggota perusahaan tersebut oleh karena para anggota itu juga ingin mencapai sasaran-sasaran tersebut. Dari pengertian di atas, pelaksanaan (actuating) tidak lain merupakan upaya untuk menjadikan perencanaan menjadi kenyataan, dengan melalui berbagai pengarahan dan pemotivasian agar setiap karyawan dapat melaksanakan kegiatan secara optimal sesuai dengan tugas dan tanggung jawabnya.

Hal yang penting untuk diperhatikan dalam pelaksanan (actuating) ini adalah bahwa seorang karyawan akan termotivasi untuk mengerjakan sesuatu jika : (1) merasa yakin akan mampu mengerjakan, (2) yakin bahwa pekerjaan tersebut memberikan manfaat bagi dirinya, (3) tidak sedang dibebani oleh problem pribadi atau tugas lain yang lebih penting, atau mendesak, (4) tugas tersebut merupakan kepercayaan bagi yang bersangkutan dan (5) hubungan antar teman dalam organisasi tersebut harmonis.

Menurut MR bapak Muslimin wawancara (6 Mei 2013) ia menyebutkan bahwa seluruh pendidik dan tenaga kependidikan di SD Islam Az-Zahrah merupakan tim sukses dalam melakukan pelayanan manajemen sekolah demi kepuasan pelanggan, baik orang tua, siswa, bahkan masyarakat secara keseluruhan. Lebih lanjut di jelaskannya bahwa mulai dari satuan pengamanan (Satpam) dan cleaning servis sebagai garda terdepan dalam memberikan pelayanan yang memuaskan kepada seluruh stake holder sekolah, dilanjutkan kebagian informasi dan tata usaha, dan selanjutnya dirujuk sesuai kebutuhan masing-masing pelanggan.

Mengenai peningkatan partisipasi masyarakat, sesuai dengan observasi yang dilakukan oleh peneliti pada (2 Mei 2013) memang seluruh masyarakat sekolah ikut ber serta dalam meningkatkan partisipasi masyarakat, seperti penyambutan siswa, orang tua atau wali murid, bahkan masyarakat pengusaha. Didalam dokumen humas yang berkaitan dengan kerjasama orang tua atau wali murid dijelaskan secara prosedural dan rinci, bahkan kerjasama kemitraan juga termaktub sebagaimana pasal 6.1 pada PK Humas; 6.1.1. Kepala sekolah memberikan arahan program kerjasama dan kemitraan yang perlu dilakukan guna menunjang peningkatan mutu sekolah. 6.1.2. Koordinator Humas menyusun program kerjasama dalam format program kerja sama.( F/HUM/05) 6.1.3. Bentuk kerjasama diketahui oleh pihak Humas dan disampaikan kepada bidang yang terkait untuk ditindak lanjuti atas 
persetujuan Kepala Sekolah. 6.1.4. Staff Humas membantu mengarsipkan hasil dan pelaksanaan kerjasama dan kemitraan.

\section{- Kontrol (Controlling).}

Menurut Muslimin (wawancara, 6 Mei 2013) proses kontrol terhadap manajemen SDI Az-Zahrah dapat dilakukan oleh kepala sekolah sebagai top manejemen. Dan Wawancara dengan Ibu Dwi Martini, bahwa kontrol dapat dilakukan secara lansung bagaimana seluruh tenaga pendidik dan kependidikan memberikan pelayanan kepada orang tua atau wali murid, masyarakat umum, pengusaha, dan sebagainya. Bahkan menurut Dwi Martini, kontrol tidak hanya dilakukan kepada pelaksana saja tetapi juga dilakukan kontrol secara berkesinambungan melalui dokumen dan papan kontrol atau komplin.

Menurut Muslimin, kontrol mengenai mutu selalu dilakukan oleh tim yang ditunjuk oleh kepala sekolah, dan menarik tim ini juga dapat melakukan kontrol kesetiap lini, termasuk kepala sekolah. Tim pertama yaitu tim pengukuran, yang bertugas mengukur kepuasan dan kepentingan pelanggan; dan tim audit internal, tim ini melakukan verifikasi kesesuai perencanaan, pendelegasian, pelaksanaan dan termasuk kontrol yang ada disetiap bidang.

Melalui observasi peneliti (4, 5 dan 6 Mei 2013) di SDI Az-Zahrah seperti kontrol kebersihan, semua pengguna dapat menuliskan komplinnya yang berkaitan dengan kebersihan, kenyamanan, keindahan, dan sebagainya di whiteboard. Dan juga orang tua atau wali murid dapat melakukan komplin terhadap pelayanan sekolah bagi pribadinya atau anaknya yang tersedia dimeja informasi.

\section{KESIMPULAN DAN SARAN}

Kepala sekolah dalam meningkatkan partisipasi masyarakat di SD Islam AzZahrah, melalui delegasi pelayanan, baik tenaga pendidik dan kependidikannya sesuai dengan potensi dan kompotensi yang dimiliki setiap individu, mereka selalu berkoordinasi untuk meningkatkan pelayanan dan kepuasan kepada siswa, orang tua atau walimurid, dan masyarakat, sehingga dengan begitu SD Islam Az-Zahrah memiliki image positif dari masyarakat sekolah yang pada akhirnya mereka mensekolahkan anak mereka atau tertarik untuk berekerjasama dari berbagai level dan kalangan masyarakat.

Image positif yang dibangun oleh kepala sekolah SD Islam Az-Zahrah berdampak positif, sehimgga secara terus-menerus orang tua mau mensekolahkan anak-anaknya di SD Islam Az-Zahrah, bagi masyarakat pengusaha mereka selalu ikut ambil dalam setiap kegiatan perlombaan yang 
bersifat edukatif, tokoh-tokoh masyarakat yang kebetulan banyak mensekolahkan anaknya ke SD Islam Az-Zahrah, lebih muda bagi kepala sekolah untuk melibatkan mereka dalam meningkatkan partisipasi masyarakat.

Partisipasi masyarakat terhadap sekolah, baik masyarakat secara umum, maupun melalui komite sekolah dalam memberikan pertimbangan (advisory agency), memberikan dukungan (supporting agency) mengawasi penyelenggaraan pendidikan di sekolah (controlling agency) dan penghubung antara sekolah dengan orangtua siswa (mediator) dapat terlaksana dengan baik di SD Islam Az-Zahrah dengan berbagai bentuk, seperti; Pemikiran dan ide, kesejahteraan pendidik, tenaga kependidikan, dan masyarakat sekitar yang membutuhkan bantuan finansial, Interpreneurship bagi siswa, guru, dan masyarakat, dan meningkatkan sumberdaya manusia bagi guru, orang tua, dan siswa, dan fieldtrif. Hal ini jugalah yang dijadikan sebagai faktor-faktor pendukung dalam meningkatkan partisipasi masyarakat di SD Islam Az-Zahrah. Karena memang manajemen sekolahnya sangat baik, mulai dari perencanaan, pendelegasian, pelaksanaan, dan kontrolnya.

Sementara faktor penghambat dalam meningkatkan partisifasi masyarakat, hususnya orang tua, mereka tidak memiliki waktu banyak untuk ikut ber secara langsung pada setiap kegiatan sekolah atau mengawasi proses manajerial pendidikan bagi anak-anak mereka.

\section{DAFTAR PUSTAKA}

Boone, L.E.\& David, L.K. (1984). Principles of Management. New York: Random House.

Handoko, T. H. (1995). Manajemen. Yogyakarta: BPFE.

Moleong, L. J. (1991). Metodologi Penelitian Kualitatif. Bandung: Rosda.

Mulyasa, E. (2011). Manajemen dan Kepemimpinan Kepala Sekolah. Jakarta: Bumi Aksara.

Nasution, M. N. (2001). Manajemen Mutu Terpadu (Total Quality Management). Jakarta: Khadafi, Gralia Indonesia.

Rivai, V., \& Murni, S. (2009). Education Management Analisi Teori dan Praktik, Jakarta: Rajawali Press.

Sagala, S. (2009). Kemampuan Profesional Guru dan Tenaga Kependidikan. Bandung: Alfa Beta.

Terry, G. R. \& Winardi. (1986). Asas-asas Manajemen. Bandung: Alumni.

Usman, H. (2007). Faktor-Faktor yang Mempengaruhi Perilaku Kepala Sekolah. Jurnal Tenaga Kependidikan, 2 (3). - (2008). Peranan Fungsi Kepala Sekolah/Madrasah. Jurnal Tenaga Kependidikan, 3(1). 